\title{
Accumulation of $\mathrm{CD69}^{+}$tissue-resident memory $\mathrm{T}$ cells in the nasal polyps of patients with chronic rhinosinusitis
}

\author{
PASCAL ICKRATH $^{1}$, NORBERT KLEINSASSER ${ }^{2}$, XIN DING $^{3}$, CHRISTIAN GINZKEY $^{4}$, \\ NIKLAS BEYERSDORF ${ }^{3}$, RUDOLF HAGEN ${ }^{1}$, THOMAS KERKAU ${ }^{3}$ and STEPHAN HACKENBERG ${ }^{1}$ \\ ${ }^{1}$ Department of Otorhinolaryngology, Plastic, Aesthetic and Reconstructive Head and Neck Surgery, \\ University of Wuerzburg, D-97080 Wuerzburg, Germany; ${ }^{2}$ Department of Otorhinolaryngology, \\ Head and Neck Surgery, Kepler University Hospital, A-4021 Linz, Austria; ${ }^{3}$ Institute for Virology and Immunobiology, \\ University of Wuerzburg, D-97080 Wuerzburg; ${ }^{4}$ Department of Otorhinolaryngology, \\ Head and Neck Surgery ‘Otto Körner', University Medical Center Rostock, D-18057 Rostock, Germany
}

Received December 3, 2017; Accepted April 16, 2018

DOI: $10.3892 / \mathrm{ijmm} .2018 .3653$

\begin{abstract}
In patients with chronic rhinosinusitis with nasal polyps (CRSwNP), a relative accumulation of cluster of differentiation (CD) $8^{+} \mathrm{T}$ cells over $\mathrm{CD} 4^{+} \mathrm{T}$ cells occurs in nasal polyps compared with the peripheral blood. Nasal $\mathrm{CD} 8^{+}$ $\mathrm{T}$ cells and $\mathrm{CD}^{+} \mathrm{T}$ cells predominantly present an effector memory phenotype. Immunological studies have reported that memory $\mathrm{T}$ cells recirculate from the tissues to the peripheral blood and a high percentage of these $\mathrm{T}$ cells persist within the tissue. The aim of the present study was to characterize $\mathrm{CD} 69^{+}$ sphingosine-1-phosphate receptor 1 (S1PR1) ${ }^{-}$tissue resident memory $\mathrm{T}$ cells $\left(\mathrm{T}_{\mathrm{rm}}\right)$ in the polyps of patients with CRSwNP. Tissue and blood samples were collected from 10 patients undergoing nasal sinus surgery. Expression of specific extraand intracellular molecules were analyzed using multicolor flow cytometry. A significantly higher level of $\mathrm{CD} 8^{+} \mathrm{T}$ cells than $\mathrm{CD}^{+} \mathrm{T}$ cells was present in nasal polyps, while significantly more $\mathrm{CD}^{+}{ }^{+} \mathrm{T}$ cells than $\mathrm{CD} 8^{+} \mathrm{T}$ cells were detected in the peripheral blood of patients with CRSwNP. The frequency of $\mathrm{CD} 9^{+} \mathrm{T}$ cells was significantly higher in $\mathrm{CD}^{+}$and $\mathrm{CD} 4^{+}$ $\mathrm{T}$ cells in nasal polyps compared with the peripheral blood. The frequency of $\mathrm{CD} 69^{+} \mathrm{S}^{\mathrm{PR}} 1^{-} \mathrm{T}_{\mathrm{rm}}$ was also significantly higher
\end{abstract}

Correspondence to: Dr Pascal Ickrath, Department of Otorhinolaryngology, Plastic, Aesthetic and Reconstructive Head and Neck Surgery, University of Wuerzburg, Josef-Schneider-Street 11, D-97080 Wuerzburg, Germany

E-mail: ickrath_p@ukw.de

Abbreviations: CRSwNP, chronic rhinosinusitis with nasal polyps; $\mathrm{T}_{\text {reg }}$, regulatory $\mathrm{T}$ cells; $\mathrm{a} \mathrm{T}_{\text {reg, }}$, activated regulatory $\mathrm{T}$ cells; $\mathrm{r}_{\text {reg }}$, resting regulatory $\mathrm{T}$ cells; Tconv, conventional $\mathrm{T}$ cells; $\mathrm{T}_{\mathrm{rm}}$, tissue-resident memory $\mathrm{T}$ cells; $\mathrm{T}_{\mathrm{em}}$, effector memory $\mathrm{T}$ cells; $\mathrm{T}_{\mathrm{cm}}$, central memory $\mathrm{T}$ cells

Key words: chronic rhinosinusitis with nasal polyps, chronic rhinosinusitis without nasal polyps, $\mathrm{T}$ cell subpopulations, regulatory $\mathrm{T}$ cells, memory $\mathrm{T}$ cells, tissue-resident memory $\mathrm{T}$ cells in $\mathrm{CD}^{+}$and $\mathrm{CD} 8^{+} \mathrm{T}$ cells from nasal polyps compared with the peripheral blood. Within polyps, the frequency of $\mathrm{CD}^{+} 9^{+}$ S1PR1- $T_{r m}$ was again significantly higher in $\mathrm{CD}^{+}$compared with $\mathrm{CD}^{+} \mathrm{T}$ cells. In summary, a significantly higher frequency of $\mathrm{CD}^{+} 9^{+} \mathrm{S} 1 \mathrm{PR} 1^{-} \mathrm{T}$ cells was observed in the nasal polyps compared with the peripheral blood in patients with CRSwNP. The results of the present study suggest that local regulation of the immune response occurs within nasal polyps. As such, $\mathrm{T}_{\mathrm{rm}}$ should be considered a potential stimulus in the pathogenesis of nasal polyps. However, the role of $\mathrm{T}_{\mathrm{rm}}$ in nasal polyps as a pathogenic trigger of the local inflammatory reaction requires further investigation.

\section{Introduction}

Chronic rhinosinusitis (CRS) can be divided into two subtypes: CRS without nasal polyps (CRSsNP) and CRS with nasal polyps (CRSwNP). CRSwNP is a heterogeneous disease with an unclear pathophysiology (1). CRSwNP is subdivided into different endotypes by inflammatory markers and/or cells that serve a role in the disease (1). One theory about the maintenance of the inflammatory reaction is a variation of $\mathrm{T}$ cells within the polypoid tissue (2). In a previous study (2), cluster of differentiation (CD) $4^{+}$and $\mathrm{CD} 8^{+} \mathrm{T}$ cell subsets were characterized by multicolor flow cytometry, which revealed a predominance of $\mathrm{CD} 8^{+} \mathrm{T}$ cells in nasal polyps compared with the peripheral blood mononuclear cells (PBMCs) in patients with CRSwNP. There was a significantly higher amount of $\mathrm{CD} 8^{+} \mathrm{T}$ cells compared with $\mathrm{CD} 4^{+} \mathrm{T}$ cells in nasal polyps, whereas there were significantly more $\mathrm{CD} 4^{+} \mathrm{T}$ cells compared with $\mathrm{CD} 8^{+}$ T cells in the PBMCs (2). These data suggest a local regulation of the immune response within nasal polyps. Furthermore, both $\mathrm{CD} 4^{+}$and $\mathrm{CD} 8^{+} \mathrm{T}$ cells were able to differentiate into an effector memory phenotype. It was postulated that variations in regulatory $\mathrm{T}$ cells are responsible for a number of autoimmune diseases (3). A previous study reported a significant increase in activated regulatory $\mathrm{T}$ cells $\left(\mathrm{T}_{\mathrm{reg}}\right)$ in polypoid tissue compared with the PBMCs in patients with CRSwNP (2). Specific triggers, including fungal colonization (4-6) or Staphylococcal 
superantigens $(7,8)$ influence $\mathrm{T}$ cell recruitment in CRSwNP and may also influence $\mathrm{T}$ cell subset composition within the polyps. Additionally, local changes in B cell subpopulations in the nasal polyps compared with PBMCs has been reported and underlines the role of lymphocytes in this disease (9).

Memory $\mathrm{T}$ cells represent the main subset of $\mathrm{CD}^{+}$and $\mathrm{CD}^{+} \mathrm{T}$ cells in polypoid tissue in patients with CRSwNP (2). These memory $\mathrm{T}$ cells can be classified into two subsets based on the expression of homing receptors, including C-C chemokine receptor 7 (CCR7) (10), into $\mathrm{CCR}^{+}$central memory T cells $\left(\mathrm{T}_{\mathrm{cm}}\right)$ and CCR7 ${ }^{-}$effector memory $\mathrm{T}$ cells $\left(\mathrm{T}_{\mathrm{em}}\right)$. After antigen presentation and differentiation into $\mathrm{T}_{\mathrm{em}}, \mathrm{T}$ cells migrate towards non-lymphoid tissue (NLT). It was previously assumed that these T cells recirculate into the PBMCs; however, immunological studies have reported persistent populations of tissue-resident memory T cells $\left(\mathrm{T}_{\mathrm{rm}}\right)$ in NLT (11). These T cells may be identified by a high expression of CD69 and a downregulation of the sphingosine-1 phosphate receptor 1 (S1PR1). $\mathrm{S} 1 \mathrm{PR} 1$ is required for naive $\mathrm{T}$ cells to circulate and exit the thymus and peripheral lymphoid organs (11). S1PR1 downregulation is an essential marker for $\mathrm{T}_{\mathrm{rm}}$ (12). In contrast, CD69 upregulation is a major signal for the persistence of $T_{r m}$ in NLT (13). Both signals are necessary for the persistence of $\mathrm{T}_{\mathrm{rm}}$ (14) in the local tissue. Chemoattractant receptors, including CCR7, also serve a role in the egress of T cells from NLT (15), therefore a downregulation in CCR7 is a sign that $\mathrm{T}$ cells persist in the tissue and do not recirculate. These $\mathrm{T}_{\mathrm{rm}}$ cells are described as being more potent in protection against local infections compared with memory $\mathrm{T}$ cells residing elsewhere (16). Furthermore, $\mathrm{T}_{\mathrm{rm}}$ have been reported to serve a role in drug hypersensitivity reactions (17).

The aim of the present study was to quantify the number of $\mathrm{CD}^{+}$and $\mathrm{CD}^{+} \mathrm{T}_{\mathrm{rm}}$ cells in the nasal polyps compared with PBMCs in patients with CRSwNP and to determine whether there were differences between these subpopulations.

\section{Materials and methods}

Ethical approval. The study was approved by the Ethics Board of the Medical Faculty, Julius-Maximilian-University, Wuerzburg, Germany. Ethics approval and written informed consent was obtained from all patients.

Preparation of human lymphocytes. A total of $10 \mathrm{ml}$ of heparinized blood samples were obtained intraoperatively by venous puncture from 10 patients undergoing paranasal sinus surgery between July and October 2017. All patients received intranasal topical steroids (mometasone furoate nasal spray, $50 \mu \mathrm{g} /$ puff) prior to surgery. Patients were recruited from the Department of Otorhinolaryngology, Plastic, Aesthetic and Reconstructive Head and Neck Surgery of the University of Wuerzburg (Wuerzburg, Germany). Patients with Churg-Strauss syndrome, primary ciliary dyskinesia or cystic fibrosis were excluded. Patient characteristics are summarized in Table I. Lymphocytes were separated by density-gradient centrifugation for $10 \mathrm{~min}$ at $1,000 \mathrm{x}$ g at room temperature with equal amounts of Ficoll (Biochrom $\mathrm{GmbH}$, Berlin, Germany), using a membrane-containing $10 \mathrm{ml}$ cell tube (Greiner Bio-One, Kremsmünster, Austria). Tubes were washed twice with PBS and the cell number and viability were determined using a Cell Counter + Analyzer System (CASY TT; Innovatis Technologies, Inc., Fairfax, VA, USA) according to the manufacturer's protocol. Following centrifugation at $500 \mathrm{x} \mathrm{g}$ at $20^{\circ} \mathrm{C}$ for $5 \mathrm{~min}$, the cells were frozen at $-80^{\circ} \mathrm{C}$ with $1 \mathrm{ml}$ freezing medium, which contained 10 parts of fetal bovine serum (Linaris Biologische Produkte $\mathrm{GmbH}$, Dossenheim, Germany) and one part dimethylsulfoxide.

Preparation oftissue samples. All tissue samples were collected intraoperatively from 10 patients undergoing regular paranasal sinus surgery due to CRSwNP. Additionally, nasal mucosa was collected from 3 patients diagnosed with CRSsNP undergoing paranasal sinus surgery between August and September 2016 at the local university. Exclusion criteria were as above. All patients were female and mean age was $45.33 \pm 17.44$. The polyps and nasal mucosa samples were cut into small fragments and mashed through a cell strainer (Greiner Bio-One) from 100 to $40 \mu \mathrm{m}$ in PBS. Tissues were washed twice in PBS and the cell number and viability were determined using a CASY TT system according to the manufacturer's protocol. Following centrifugation for $5 \mathrm{~min}$ at, 1,600 rpm, cells were frozen at $-80^{\circ} \mathrm{C}$ in $1 \mathrm{ml}$ freezing medium.

Fluorescence-activated cell sorting. The following antibodies were used: Anti-CD45 Pacific Orange (1:300; MHCD4530; Thermo Fisher Scientific Inc., Waltham, MA, USA), anti-CD3 phycoerythrin (PE)-Cy7 (1:300; 300420;) anti-CD4 Pacific Blue (1:50, Nr. 300521), anti-CD8a Alexa 700 (1:50, 301028) anti-CD45RA peridinin chlorophyll protein complex-Cy5.5 (1:50; 304122), anti-CCR7 Alexa488 (1:80; 353206), anti-CD69 Alexa 488 (1:50, Nr. 310916), anti CD69 allophycocyanin (APC; $1: 50 ; 310909)$, anti-CD4 fluorescein isothiocyanate (1:40; 300506), anti-FoxP3 Pacific Blue (1:25; 320216) anti-CD52 (CTLA-4) PE (1:400;349906; all BioLegend, Inc., San Diego, CA, USA) and anti-S1PR1 eFluor 660 (1:20; 50-3639-41; eBioscience; Thermo Fisher Scientific, Inc.). Isotype control staining was performed using mouse-IgG APC (1:80; 137214) and mouse-IgG PE (1:25; 400140) (BioLegend, Inc.). Viability Dye 780(1:10;65-0865-14; eBioscience; ThermoFisherScientific, Inc.) was used to detect apoptotic and dead cells. Following blocking with $25 \mu \mathrm{g} / \mathrm{ml}$ normal mouse immunoglobulin $\mathrm{G}$ (1:50, Nr. I5381, Sigma-Aldrich; Merck KGaA, Darmstadt, Germany) for $15 \mathrm{~min}$ on ice, all cells underwent cell surface staining on ice for $30 \mathrm{~min}$, followed by intracellular staining. For intracellular staining of Foxp3 and CTLA-4, cells were treated with fixation buffer (eBioscience; Thermo Fisher Scientific, Inc.) for $30 \mathrm{~min}$ at room temperature. Permeabilisation buffer was subsequently applied (eBioscience; Thermo Fisher Scientific, Inc.) followed by staining with anti-Foxp3 and anti-CTLA-4 for $45 \mathrm{~min}$ at room temperature. All antibodies were used according to the manufacturer's protocol. FACS analysis was performed using an LSR II flow cytometer and the data were analyzed using FlowJo software (FlowJo LLC, Ashland, OR, USA).

Statistical analysis. Data are presented as mean \pm standard deviation. Statistical significance was analyzed by a two-tailed paired t-test using GraphPad Prism Software 6.0c (GraphPad Software, Inc., La Jolla, CA, USA). For non-parametric distribution the Wilcoxon test was applied. $\mathrm{P}<0.05$ was considered to indicate a statistically significant difference. 


\section{Results}

Patient characteristics. A total of 10 patients with CRSwNP were included in the present study (8 male and 2 female). The mean age was $45 \pm 9.48$ years. Eosinophilic polyposis was described in the histological evaluation of most of the patients (7/10). Patient characteristics are summarized in Table I.

Higher frequency of $C D 69^{+}$cells in $C D 4^{+}$and $C D 8^{+} T$ cells in $C R S w N P$. The amount of $\mathrm{CD}^{+} \mathrm{CD}^{+} \mathrm{T}$ cells among $\mathrm{CD} 45^{+}$ leukocytes was significantly higher in PBMCs compared with in nasal polyps from patients with CRSwNP (Table II). In contrast, $\mathrm{CD}^{+} \mathrm{CD}^{+} \mathrm{T}$ cells were significantly increased in nasal polyps compared with PBMCs (Table II). A significant increase in the frequency of CD69-expressing cells was observed among $\mathrm{CD}^{+}$ $\mathrm{CD}^{+}$and $\mathrm{CD}^{+}{ }^{+} \mathrm{CD} 8^{+} \mathrm{T}$ cells in the nasal polyps compared with PBMCs (Table II; Fig. 1). However, these cells did not constitute recently activated $\mathrm{T}$ cells, as $\mathrm{T}$ cells from nasal polyps do not express elevated levels of human leukocyte antigen-antigen D related (HLA-DR) compared with PBMCs (2). In PBMCs, a majority of cells were CD69- (Table II; Fig. 1). The percentage of $\mathrm{CD} 69^{+}$cells was significantly higher among $\mathrm{CD} 8^{+}$compared with $\mathrm{CD}^{+} \mathrm{T}$ cells in PBMCs and polyps (Table II).

S1PRl expression in $\mathrm{CD}^{+}$and $C D 8^{+}$T cells in $C R S w N P$. The percentage of $\mathrm{S}_{\mathrm{PR}} 1^{+}$between $\mathrm{CD}^{+}{ }^{+}$and $\mathrm{CD}^{+} \mathrm{T}$ cells was significantly higher in nasal polyps compared with PBMCs (Table II; Fig. 2). This is most likely attributable to down modulation of S1PR1 expression by its ligand S1P, which is abundantly present in PBMCs (18). In PBMCs the proportion of cells expressing S1PR1 was significantly higher among $\mathrm{CD}^{+} \mathrm{T}$ cells compared with $\mathrm{CD} 4^{+} \mathrm{T}$ cells, whereas no significant difference in S1PR1 expression was observed between $\mathrm{CD}^{+}$and $\mathrm{CD}^{+} \mathrm{T}$ cells in nasal polyps (Table II).

CD69 $^{+}$S1PR1- $T_{r m}$ was significantly increased in nasal polyps compared with PBMCs. In patients with CRSwNP, the frequency of $\mathrm{CD} 9^{+} \mathrm{S}^{+} \mathrm{PR} 1^{-} \mathrm{T}_{\mathrm{rm}}$ in $\mathrm{CD}^{+}$and $\mathrm{CD}^{+} \mathrm{T}$ cells was significantly higher in nasal polyps compared with PBMCs (Table II; Fig. 3). CD8 ${ }^{+}$T cells contained more $\mathrm{CD}^{+} 9^{+}$ S1PR1- $\mathrm{T}_{\mathrm{rm}}$ compared with $\mathrm{CD} 4^{+} \mathrm{T}$ cells, irrespective of the anatomical compartment analyzed (Table II).

CD69 overexpression, activated $T_{\text {reg }}\left(a T_{\text {reg }}\right)$ and conventional memory T cells (Tconv) in CRSwNP. Further analysis of CD4 ${ }^{+}$ $\mathrm{T}$ cell subsets with respect to CD45RA and FoxP3 expression revealed significantly more $\mathrm{CD}^{+} \mathrm{CD}^{+}{ }^{+} \mathrm{CD} 45 \mathrm{RA}^{+} \mathrm{FoxP}^{+}$ naïve $\mathrm{T}$ cells in PBMCs compared with nasal polyps in patients with CRSwNP (Table III). However, CD69 expression was significantly higher in phenotypically naïve $\mathrm{CD}^{+} \mathrm{T}$ cells in nasal polyps compared with PBMCs (Table III; Fig. 4). The number of CD45RA- FoxP3- conventional $\mathrm{T}_{\text {conv }}$ cells was significantly higher among $\mathrm{CD}^{+} \mathrm{T}$ cells in nasal polyps with significantly higher expression of CD69 in these cells compared with PBMCs (Table III; Fig. 4). The proportion of CD45RA- FoxP3 ${ }^{\text {low }}$ memory $\mathrm{T}$ cells with Th17 potential was significantly elevated among $\mathrm{CD}^{+} \mathrm{T}$ cells in nasal polyps, while CD69 expression was also significantly higher in these cells in nasal polyps compared with PBMCs (Table III; Fig. 4). Percentages of $\mathrm{CD}^{+} \mathrm{CD}^{+} 5 \mathrm{RA}^{+}$FoxP $3^{\text {low }}$ resting $\mathrm{T}_{\text {reg }}\left(\mathrm{rT}_{\text {reg }}\right)$ were
Table I. Baseline characteristics of the study group.

Clinical feature

Study group $(n=10)$

Age, years (standard deviation)

$44(9.48)$

Sex, female/male $2 / 8$

Previous surgery, n (\%)

Eosinophilic polyps, $\mathrm{n}(\%)$

Allergy, n (\%)

Samter's triad, n $(\%)$

not significantly different in PBMCs and polyps (Table III). In contrast, $\mathrm{CD}^{+} \mathrm{T}$ cells in nasal polyps from patients with CRSwNP contained significantly more CD45RA- FoxP3 ${ }^{\text {high }}$ $\mathrm{aT}_{\text {reg }}$ compared with in PBMCs (Table III). $\mathrm{rT}_{\text {reg }}$ and $\mathrm{aT}_{\text {reg }}$ cells harbored significantly more $\mathrm{CD} 69^{+}$cells in nasal polyps compared with in PBMCs (Table III; Fig. 4). In nasal polyps, $\mathrm{aT}_{\mathrm{reg}}$ contained significantly more $\mathrm{CD} 69^{+}$cells compared with $\mathrm{rT}_{\text {reg }}$ (Fig. 4). Among the different $\mathrm{CD}^{+} \mathrm{T}$ cell subsets in nasal polyps, $\mathrm{aT}_{\text {reg }}$ had the highest number of CD69-expressing cells followed by $\mathrm{T}_{\text {conv }}$ (Table III).

Homing receptor $\mathrm{CCR} 7$ on $\mathrm{CD}^{+}$and $C D 8^{+}$T cells in $C R S w N P$. A significantly reduced proportion of $\mathrm{CCR} 7^{+}$cells among $\mathrm{CD} 3^{+}$ $\mathrm{CD}^{+}$and $\mathrm{CD}^{+} \mathrm{CD}^{+} \mathrm{T}$ cells was apparent in nasal polyps compared with PBMCs (Table II). $\mathrm{CD}^{+} \mathrm{T}$ cells had a significantly lower incidence of $\mathrm{CCR} 7^{+}$cells compared with $\mathrm{CD} 4^{+}$ $\mathrm{T}$ cells in nasal polyps and PBMCs (Table II).

Lack of $\mathrm{CD}^{+}$and $C D 8^{+} T$ cells in CRSSNP. Evaluation of lymphocytes in the nasal mucosa of patients with CRSsNP was not possible due to the low amounts of these cells in the tissue harvested intraoperatively. Only cell counts between 3 and 207 were found for $\mathrm{CD}^{+}$and $\mathrm{CD}^{+} \mathrm{T}$ cells, thus a statistically appropriate analysis was not possible. For this reason, a comparison of $\mathrm{T}$ cell subsets in samples from patients with CRsSNP and CRSwNP was not possible in the present study.

\section{Discussion}

In the present study, a detailed quantification of $\mathrm{T}_{\mathrm{rm}}$ in PBMCs and nasal polyps from patients with CRSwNP is presented. Percentages of $\mathrm{CD}^{6} 9^{+}$cells were significantly increased in nasal polyps compared with PBMCs. Furthermore, the incidence of $\mathrm{CD}^{2} 9^{+}$cells was significantly higher among $\mathrm{CD} 8^{+} \mathrm{T}$ cells compared with $\mathrm{CD}^{+} \mathrm{T}$ cells in polypoid tissue. Extending the analysis to S1PR1 expression, the proportion of $\mathrm{CD}^{+} 9^{+} \mathrm{S} 1 \mathrm{PR} 1^{-}$ $\mathrm{T}_{\mathrm{rm}}$ cells was significantly increased among both $\mathrm{CD}^{+}$and $\mathrm{CD}^{+} \mathrm{T}$ cells in nasal polyps compared with PBMCs in patients with CRSwNP. Furthermore, the number of CD69+ ${ }^{+} 1 P R 1^{-} \mathrm{T}_{\mathrm{rm}}$ was significantly higher among $\mathrm{CD}^{+}$compared with $\mathrm{CD}^{+}$ $\mathrm{T}$ cells. The frequency of $\mathrm{S} 1 \mathrm{PR} 1^{+}$cells was also significantly increased in edaphic $\mathrm{CD}^{+}$and $\mathrm{CD}^{+} \mathrm{T}$ cells compared with PBMCs. Thus, the number of $\mathrm{T}_{\mathrm{rm}}$ identified by double staining of CD69 and S1PR1 was lower compared with CD69 alone. Nonetheless, the percentage of CCR7 $7^{-}$cells was significantly increased among $\mathrm{CD}^{+}$and $\mathrm{CD}^{+} \mathrm{T}$ cells in edaphic lymphocytes compared with PBMCs in patients with CRSwNP. 
Table II. Comparison of $\mathrm{CD}^{+}$and $\mathrm{CD}^{+} \mathrm{T}_{\mathrm{rm}}$ cells in patients with CRSwNP.

\begin{tabular}{|c|c|c|c|}
\hline $\mathrm{T}$ cells & PBMCs & Nasal polyps & P-value \\
\hline $\mathrm{CD}^{+}{ }^{+} \mathrm{CD} 4^{+} \mathrm{T}$ cells & $37.47 \pm 10.18$ & $20.67 \pm 8.71$ & 0.0002 \\
\hline $\mathrm{CD}^{+}{ }^{+} \mathrm{CD} 69^{+} \mathrm{T}_{\mathrm{rm}}$ & $0.27 \pm 0.13$ & $38.25 \pm 14.23$ & $<0.0001$ \\
\hline $\mathrm{CD}_{4}{ }^{+} \mathrm{CD} 69^{+} \mathrm{S} 1 \mathrm{PR} 1^{-} \mathrm{T}_{\mathrm{rm}}$ & $0.28 \pm 0.13$ & $23.61 \pm 15.26$ & 0.0013 \\
\hline $\mathrm{CD}^{+} \mathrm{CCR}^{-} \mathrm{T}_{\mathrm{rm}}$ & $66.06 \pm 20.21$ & $85.16 \pm 14.29$ & 0.0093 \\
\hline $\mathrm{CD}^{+} \mathrm{S} 1 \mathrm{PR} 1^{+} \mathrm{T}$ cells & $4.56 \pm 6.46$ & $33.82 \pm 27.98$ & 0.0098 \\
\hline $\mathrm{CD}^{+} \mathrm{CD}^{+} \mathrm{T}$ cells & $23.7 \pm 7.24$ & $40.2 \pm 15.6$ & 0.0089 \\
\hline $\mathrm{CD}^{+} \mathrm{CD}^{2} 9^{+} \mathrm{T}_{\mathrm{rm}}$ & $1.14 \pm 0.36$ & $63.24 \pm 18.83$ & $<0.0001$ \\
\hline $\mathrm{CD}^{+} \mathrm{CD}^{2} 9^{+} \mathrm{S} 1 \mathrm{PR} 1^{-} \mathrm{T}_{\mathrm{rm}}$ & $0.95 \pm 0.23$ & $35.36 \pm 23.57$ & 0.0017 \\
\hline $\mathrm{CD}^{+} \mathrm{CCR}^{-} \mathrm{T}_{\mathrm{rm}}$ & $79.04 \pm 13.43$ & $97.18 \pm 5.48$ & 0.0018 \\
\hline $\mathrm{CD}^{+} \mathrm{S} 1 \mathrm{PR} 1^{+} \mathrm{T}$ cells & $9.51 \pm 13.44$ & $38.08 \pm 31.52$ & 0.0488 \\
\hline
\end{tabular}

PBMCs, peripheral blood mononuclear cells; $\mathrm{CD}$, cluster of differentiation; $\mathrm{T}_{\mathrm{rm}}$, tissue-resident memory T cells; $\mathrm{S} 1 \mathrm{PR} 1$, sphingosine-1-phosphate receptor 1.
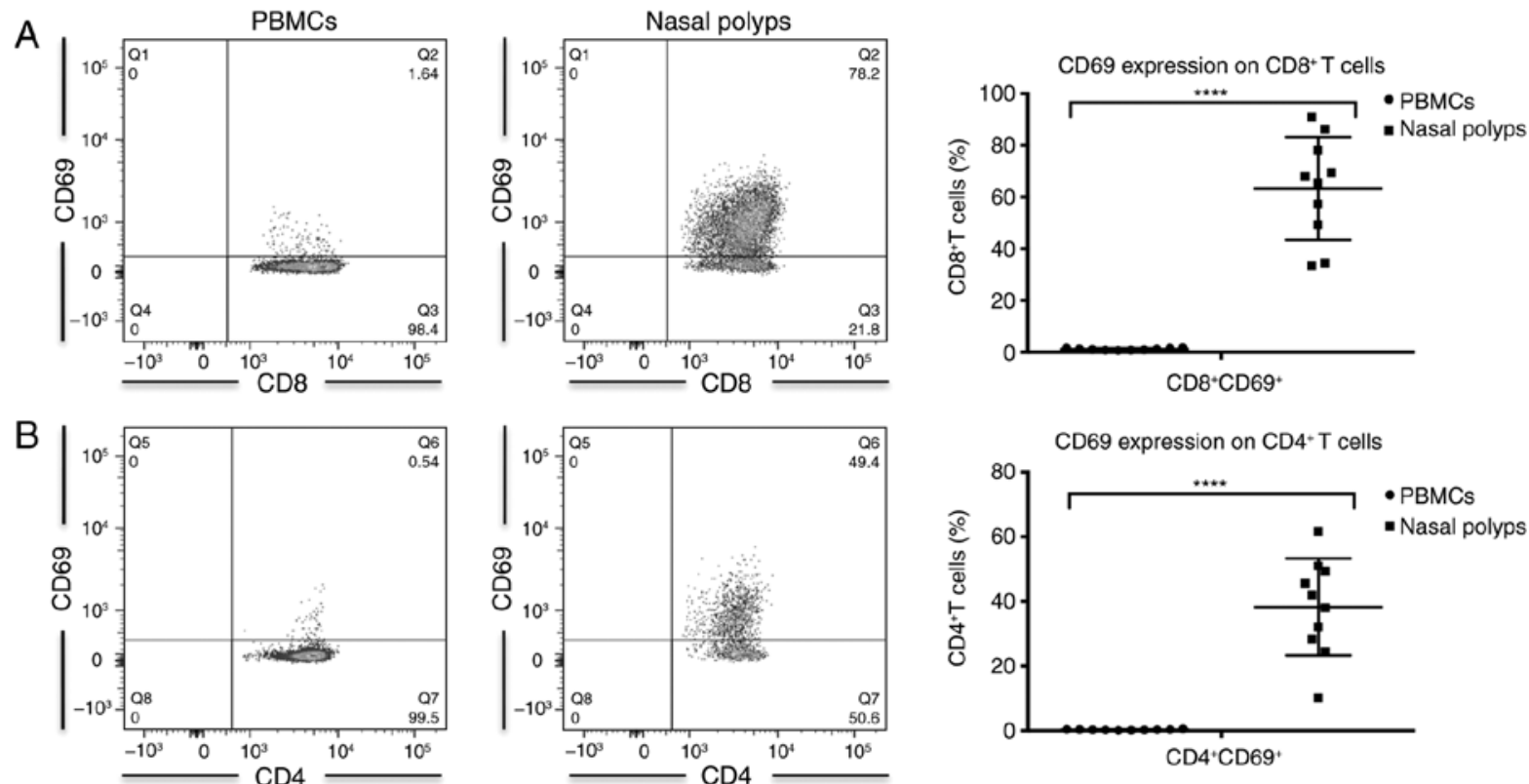

Figure 1. Expression of CD69 in (A) $\mathrm{CD}^{+} \mathrm{T}$ cells and (B) $\mathrm{CD} 4^{+} \mathrm{T}$ cells in PBMCs and nasal polyps in patients with chronic rhinosinusitis with nasal polyps Data are presented as the mean \pm standard deviation of 10 patients. ${ }^{* * * *} \mathrm{P}<0.0001$. CD, cluster of differentiation; PBMC, peripheral blood mononuclear cell.

Effector memory $\mathrm{T}$ cells migrate from PBMCs into the local tissue as a result of acute infection. Following further differentiation into $\mathrm{T}_{\mathrm{rm}}$, a high percentage of these cells will remain in the local tissue (19). Ma et al (19) discussed transforming growth factor (TGF)- $\beta$ as one of the major signals for the differentiation of kidney-resident $\mathrm{T}$ cells. However, TGF- $\beta$-independent differentiation of $\mathrm{T}_{\mathrm{rm}}$ in the intestinal lamina propria has also been reported (20). In CRSwNP, an accumulation of effector $\mathrm{CD} 4^{+}$and $\mathrm{CD} 8^{+} \mathrm{T}$ cells has been discussed (2). TGF- $\beta$ concentrations in CRSwNP differ from CRSsNP and vary between patients from different countries (21). Therefore, future studies should focus on the possible factors that drive $\mathrm{T}_{\mathrm{rm}}$ generation in CRSwNP.

Different subsets of tissue-resident lymphocytes have previously been described (22). Tissue residency was mainly attributed to $\mathrm{CD} 8^{+} \mathrm{T}$ cells and they were observed in many different organs $(23,24)$. Memory $\mathrm{T}$ cells were subdivided into $\mathrm{T}_{\mathrm{cm}}$ and $\mathrm{T}_{\mathrm{em}}$ by the homing receptor CCR7 (25). In the present study, high numbers of $\mathrm{CD} 8^{+} \mathrm{CCR} 7^{-} \mathrm{T}_{\mathrm{em}}$ were identified in nasal polyps compared with PBMCs from patients with CRSwNP. The characterization of $\mathrm{CD}^{+} \mathrm{T}_{\mathrm{rm}}$ is heterogeneous, often lacking CCR7 and highly expressing CD69 $(15,26)$. In the present study, significantly more $\mathrm{CD} 8^{+} \mathrm{T}$ cells were observed in nasal polyps compared with in PBMCs. Almost 97\% lacked the homing receptor $\mathrm{CCR} 7$ and $\sim 63 \%$ of these $\mathrm{CD} 8^{+} \mathrm{T}$ cells were $\mathrm{CD}_{69}{ }^{+}$. Whether $\mathrm{T}_{\mathrm{rm}}$ depend (27) on specific antigen presentation or not (24) remains controversial. However, a low incidence of HLA-DR-expressing T cells in nasal polyps (2) suggests that repeated antigenic stimulation is not responsible for maintaining $\mathrm{T}$ cells within the polyps. Rather, multiple triggers serve a role in this chronic disease, including fungal (4-6) infections or staphylococcal $(7,8)$ superantigens, which may 

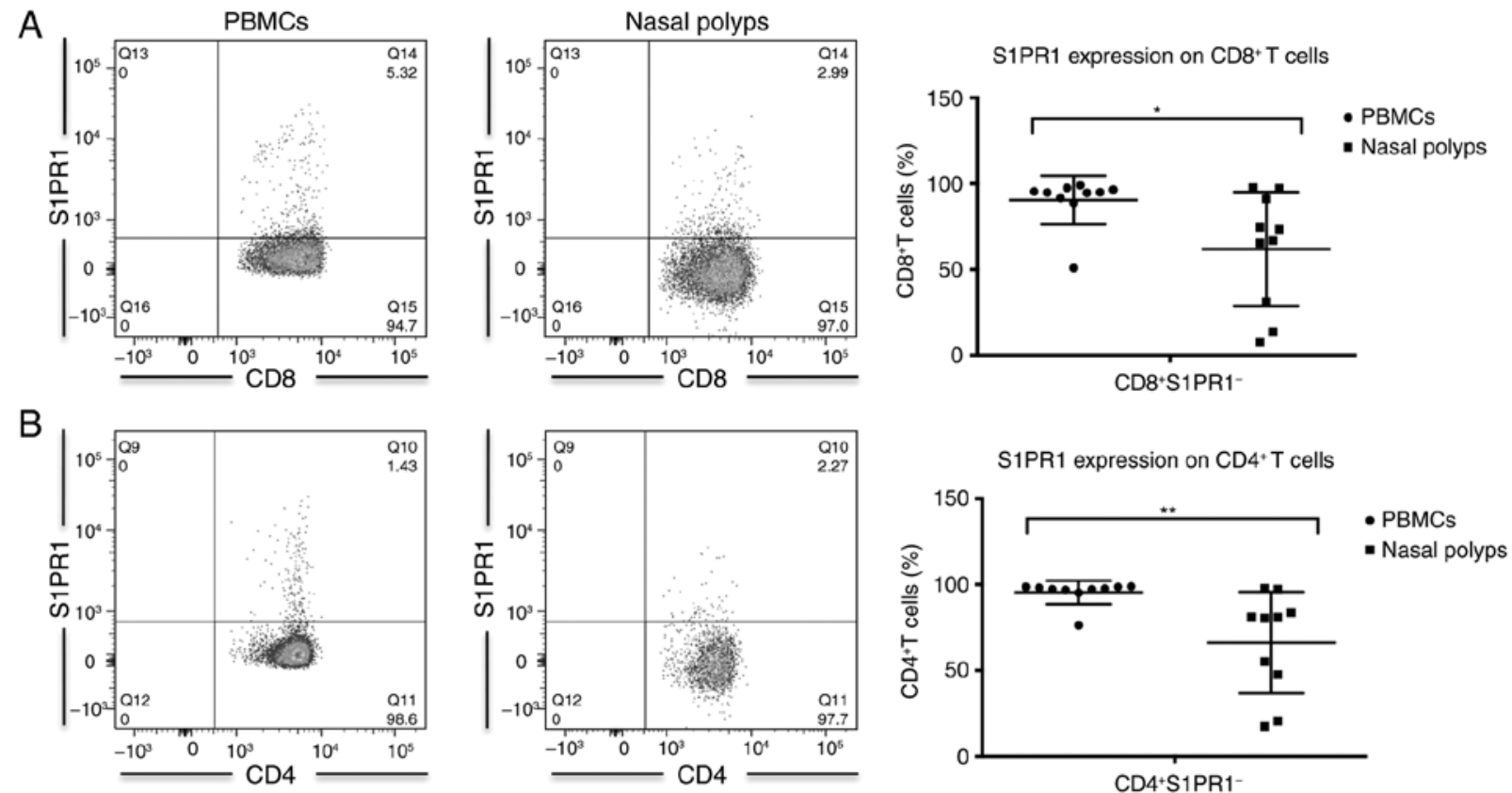

Figure 2. Expression of S1PR1 in (A) CD8 ${ }^{+} \mathrm{T}$ cells and (B) $\mathrm{CD} 4^{+} \mathrm{T}$ cells in PBMCs and nasal polyps in patients with chronic rhinosinusitis with nasal polyps Data are presented as the mean \pm standard deviation of 10 patients. ${ }^{*} \mathrm{P}<0.05$ and $^{* *} \mathrm{P}<0.01$. S1PR1, sphingosine-1-phosphate receptor 1 ; $\mathrm{CD}$, cluster of differentiation; PBMC, peripheral blood mononuclear cell.

A

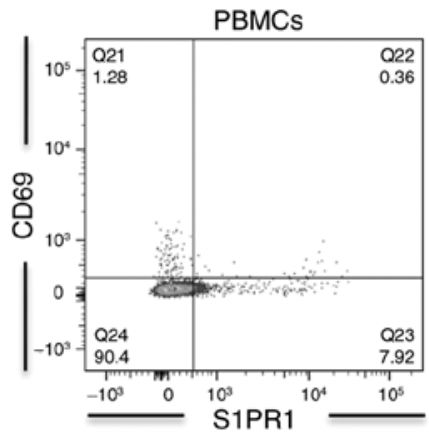

B

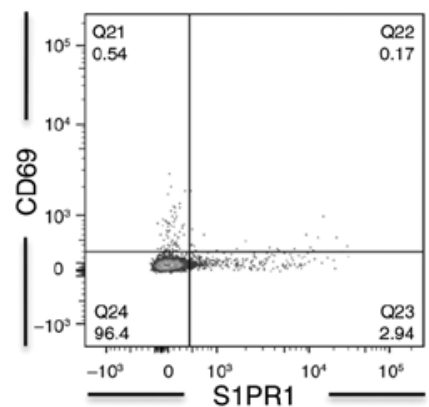

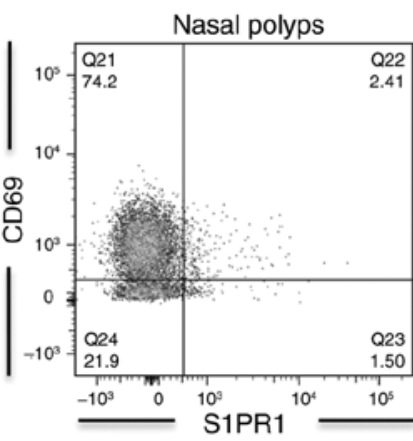
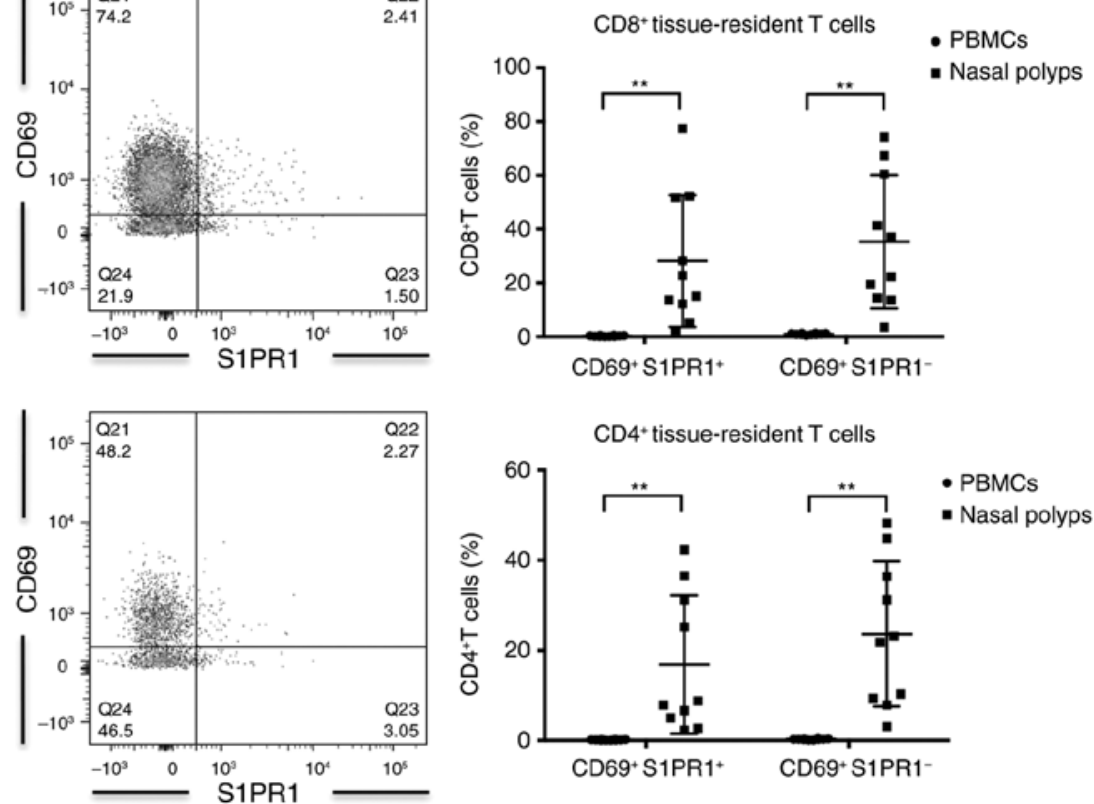

Figure 3. Expression of CD69 and S1PR1 in (A) CD8 ${ }^{+} \mathrm{T}$ cells and (B) CD4 ${ }^{+} \mathrm{T}$ cells in PBMCs and nasal polyps in patients with chronic rhinosinusitis with nasal polyps. Data are presented as the mean \pm standard deviation of 10 patients. ${ }^{* *} \mathrm{P}<0.01$. CD, cluster of differentiation; S1PR1, sphingosine-1-phosphate receptor 1; PBMC, peripheral blood mononuclear cell.

generate a niche for $\mathrm{T}_{\mathrm{rm}}$ development and maintenance independent of antigens.

Similar to $\mathrm{CD} 8^{+} \mathrm{T}_{\mathrm{rm}}, \mathrm{CD}^{+} \mathrm{T}_{\mathrm{rm}}$ are described as $\mathrm{CD} 69^{+}$ $\mathrm{T}$ cells and lack the homing receptor CCR7. In the present study, $\sim 38 \%$ of the $\mathrm{CD} 4^{+} \mathrm{T}$ cells were also positive for $\mathrm{CD} 69$ and $85 \%$ lacked the homing receptor CCR7, which suggests a high percentage of $\mathrm{CD}^{+} \mathrm{T}_{\mathrm{rm}}$ in nasal polyps. Interestingly, $\mathrm{CD} 8^{+} \mathrm{CD} 69^{+} \mathrm{T}_{\mathrm{rm}}$ were significantly increased compared with
$\mathrm{CD} 4{ }^{+} \mathrm{CD} 69^{+} \mathrm{T}$ cells in nasal polyps. The reason for higher $\mathrm{CD} 8^{+}$than $\mathrm{CD}^{+} \mathrm{T}_{\mathrm{rm}}$ numbers in polyps remains unclear and should be the focus of future studies. Besides identical expression of CD69, CCR7 and S1PR1 in CD4 $4^{+}$and $\mathrm{CD}^{+} \mathrm{T}$ cells, the signals for tissue residency are differentially described for $\mathrm{CD}^{+}$compared with $\mathrm{CD} 8^{+} \mathrm{T}_{\mathrm{rm}}$ in the literature (28). The precise mechanisms for keeping these $\mathrm{T}$ cells inside the tissue are still unclear. 
Table III. CD4 ${ }^{+}$T cell subpopulations and their CD69 expression.

\begin{tabular}{|c|c|c|c|}
\hline $\mathrm{CD}^{+}{ }^{+} \mathrm{CD} 4^{+} \mathrm{T}$ cells & PBMCs & Nasal polyps & P-value \\
\hline $\mathrm{CD}_{45 \mathrm{RA}^{+}}$FoxP $^{\text {low }}{ }^{\mathrm{CTLA}}-4^{\text {low }}$ resting $\mathrm{T}_{\text {reg }}$ & $0.52 \pm 0.30$ & $1.24 \pm 1.41$ & 0.275 \\
\hline $\mathrm{CD}^{+} 9^{+}$ & $4.81 \pm 3.99$ & $61.26 \pm 31.97$ & $<0.0001$ \\
\hline $\mathrm{CD}^{4} 5 \mathrm{RA}^{-}$FoxP3 ${ }^{\text {high }}$ CTLA-4 $4^{\text {high }}$ activated $\mathrm{T}_{\text {reg }}$ & $1.29 \pm 0.82$ & $5.74 \pm 2.18$ & 0.0004 \\
\hline $\mathrm{CD}^{+} 9^{+}$ & $3.78 \pm 2.42$ & $86.01 \pm 10.68$ & $<0.0001$ \\
\hline CD45RA- Foxp $3^{\text {low }}$ memory T cells & $3.63 \pm 1.26$ & $6.6 \pm 1.45$ & 0.0004 \\
\hline $\mathrm{CD}^{+} 9^{+}$ & $1.99 \pm 0.76$ & $67.75 \pm 13.74$ & 0.002 \\
\hline CD45RA- Foxp3- memory T cells & $56.87 \pm 16.27$ & $74.73 \pm 8.88$ & 0.014 \\
\hline $\mathrm{CD}^{+} 9^{+}$ & $2.23 \pm 0.64$ & $64.15 \pm 8.15$ & $<0.0001$ \\
\hline $\mathrm{CD}^{4} 5 \mathrm{RA}^{+}{ }^{-}$Foxp $3^{-}$naïve $\mathrm{T}$ cells & $37.83 \pm 16.64$ & $11.01 \pm 9.90$ & 0.002 \\
\hline $\mathrm{CD}^{+} 9^{+}$ & $2.33 \pm 0.72$ & $14.69 \pm 10.27$ & 0.002 \\
\hline
\end{tabular}

Data are presented as the mean \pm standard deviation of 10 patients. $\mathrm{CD}$, cluster of differentiation; PBMCs, peripheral blood mononuclear cells; $\mathrm{T}_{\text {reg }}$, regulatory $\mathrm{T}$ cells.

Another subpopulation of $\mathrm{CD}^{+}{ }^{+} \mathrm{T}$ cells which are responsible for several autoimmune disorders are $\mathrm{T}_{\text {reg }}$ cells $(29,30)$. Lynch et al (31) reported that $\mathrm{T}_{\text {reg }}$ do not recirculate in the blood. In contrast, Luo et al (32) demonstrated that $\mathrm{T}_{\text {reg }}$ do not persist in the local tissue for a long period of time. Like CD4 ${ }^{+}$ and $\mathrm{CD}^{+} \mathrm{T}_{\mathrm{rm}}, \mathrm{T}_{\text {reg }}$ require the expression of CD69 as a signal to remain in the local tissue (22). In the present study, $\mathrm{T}_{\text {reg }}$ were differentiated into $\mathrm{CD}^{+} \mathrm{CD} 4{ }^{+} \mathrm{CD} 45 \mathrm{RA}^{+} \mathrm{FoxP}^{\text {low }} \mathrm{rT}_{\text {reg }}$ and $\mathrm{CD}^{+} \mathrm{CD}^{+}{ }^{+} \mathrm{CD}_{45 \mathrm{RA}^{-} \text {FoxP3 }}{ }^{\text {high }} \mathrm{aT}_{\text {reg }} . \mathrm{rT}_{\text {reg }}$ and $\mathrm{aT}_{\text {reg }}$ exhibited a significantly higher expression of CD69 in nasal polyps compared with PBMCs. In nasal polyps, $\mathrm{aT}_{\text {reg }}$ had a significantly higher CD69 expression compared with $\mathrm{rT}_{\text {reg. }}$. These findings suggest that $T_{\text {reg }}$ populations in the polyps primarily consist of tissue-resident cells.

Skon et al (12) critically remarked that CCR7 downregulation alone is not a reliable marker for $\mathrm{T}_{\mathrm{rm}}$. For a more appropriate characterization of $\mathrm{T}_{\mathrm{rm}}$, evidence of S1PR1 downregulation is required $(12,13)$. Following detection of its ligand, S1P, S1PR1 is a necessary signal for naïve lymphocytes to exit the local tissue and recirculate (11). CD69/S1PR1 double staining revealed significantly more $\mathrm{CD}^{+}{ }^{+} \mathrm{CD}^{+}{ }^{+}$and $\mathrm{CD}^{+}{ }^{+} \mathrm{CD} 8^{+} \mathrm{CD} 69^{+}$ S1PR1 $1^{-} \mathrm{T}_{\mathrm{rm}}$ in nasal polyps compared with PBMCs in patients with CRSwNP. Furthermore, the frequency of CD69+ S1PR1 $\mathrm{T}_{\mathrm{rm}}$ was significantly higher among $\mathrm{CD} 8^{+}$compared with $\mathrm{CD} 4^{+}$ $\mathrm{T}$ cells, which underscores the dominating role of $\mathrm{CD}^{+} \mathrm{T}$ cells in CRSwNP. Interestingly, the expression of S1PR1 alone was significantly higher in total $\mathrm{CD}^{+} \mathrm{CD}^{+}$and $\mathrm{CD}^{+} \mathrm{CD}^{+}$ $\mathrm{T}$ cells from nasal polyps compared with PBMCs. This may be because S1PR1 expression is modulated by the binding of S1P and there is a high concentration of this ligand in PBMCs, with a downregulation on lymphocytes in PBMCs (18).

The pathophysiological function of $\mathrm{T}_{\mathrm{rm}}$ has been described in the literature. They are regarded as a potent sentinel mechanism against acute re-infections, thereby supporting protective immunity (14). In contrast, whether a high percentage of $\mathrm{T}_{\mathrm{rm}}$ in chronic diseases, including CRSwNP, may act as a possible pathogenic trigger of the disease itself or of early-onset recurrence following therapy remains unclear. Schmidt et al discussed allergen-specific $\mathrm{CD}^{+} \mathrm{T}_{\mathrm{rm}}$ as key mediators for acute contact dermatitis (33). In addition, they may be responsible for the development of novel sensitizations (33). Park et al (34) outlined the important role of accumulating resident memory T cells in a various diseases of barrier and non-barrier tissues. Furthermore, pathological accumulation of hyperactive $T_{r m}$ as a response to an extended inflammatory reaction may lead to further disease (34).

One limitation of the present study is the lack of a control group comprising the nasal mucosa of patients with CRSsNP. It is therefore difficult to assess whether the accumulation of $\mathrm{T}_{\mathrm{rm}}$ in nasal polyps is pathological or the normal physiological condition. An analysis of lymphocytes from the nasal mucosa of patients with CRSsNP was attempted, however the number of cells was too small for a reliable evaluation. As very few lymphocytes were able to be isolated from the nasal mucosa of patients with CRSsNP, an accumulation of $\mathrm{T}_{\mathrm{rm}}$ seems unlikely. Sathaliyawala et al (35) performed a unique analysis of human $\mathrm{T}$ cells in healthy lymphoid and mucosal tissue obtained from individual donors, thus describing a steady state of $\mathrm{T}$ cells. Interestingly, the majority of $\mathrm{T}_{\mathrm{rm}}$ identified, even in respiratory mucosae, were $\mathrm{CD}^{+}$memory $\mathrm{T}$ cells. This is in contrast to the present study in which the majority of $\mathrm{T}_{\mathrm{rm}}$ in polypoid tissue were $\mathrm{CD}^{+} \mathrm{T}$ cells. This suggests a pathological increase in the percentage of $\mathrm{CD}^{+} \mathrm{T}_{\mathrm{rm}}$ in compared with in healthy respiratory mucosae from patients with CRSwNP.

Summarizing the findings of this study and the data in the literature, there are two different $\mathrm{T}$ cell pools in nasal polyps: A high percentage of $\mathrm{CD}^{+} \mathrm{T}_{\mathrm{rm}}$ and a lower percentage of predominantly $\mathrm{CD}^{+} \mathrm{T}_{\mathrm{em}}$. Interestingly, these $\mathrm{T}$ cells are HLA-DR ${ }^{-}$(2), therefore there are no recently activated $\mathrm{T}$ cells in the polypoid tissue. $\mathrm{T}_{\mathrm{rm}}$ may be important mediators of the chronic inflammatory process in CRSwNP. Selective inhibition, or eliminating these cells by modifying their ability to persistently reside in tissue, may be a possible approach for the development of novel therapeutic strategies (34). Hypothetically, targeting and blocking CD69 could, for example, support the elimination of pathogenic $T_{r m}$ in the tissue. The clinical impact of $\mathrm{T}_{\mathrm{rm}}$ in recurrent CRSwNP should be further investigated in the future. 

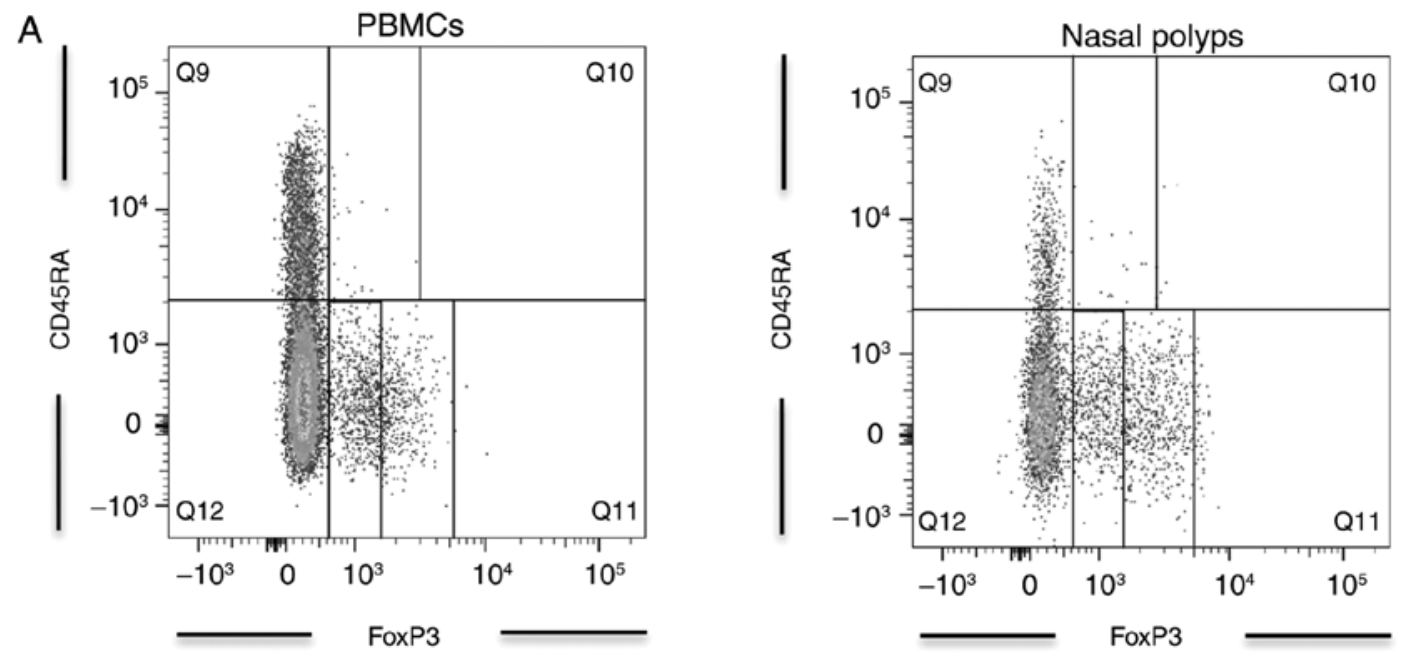

$\mathrm{B}$
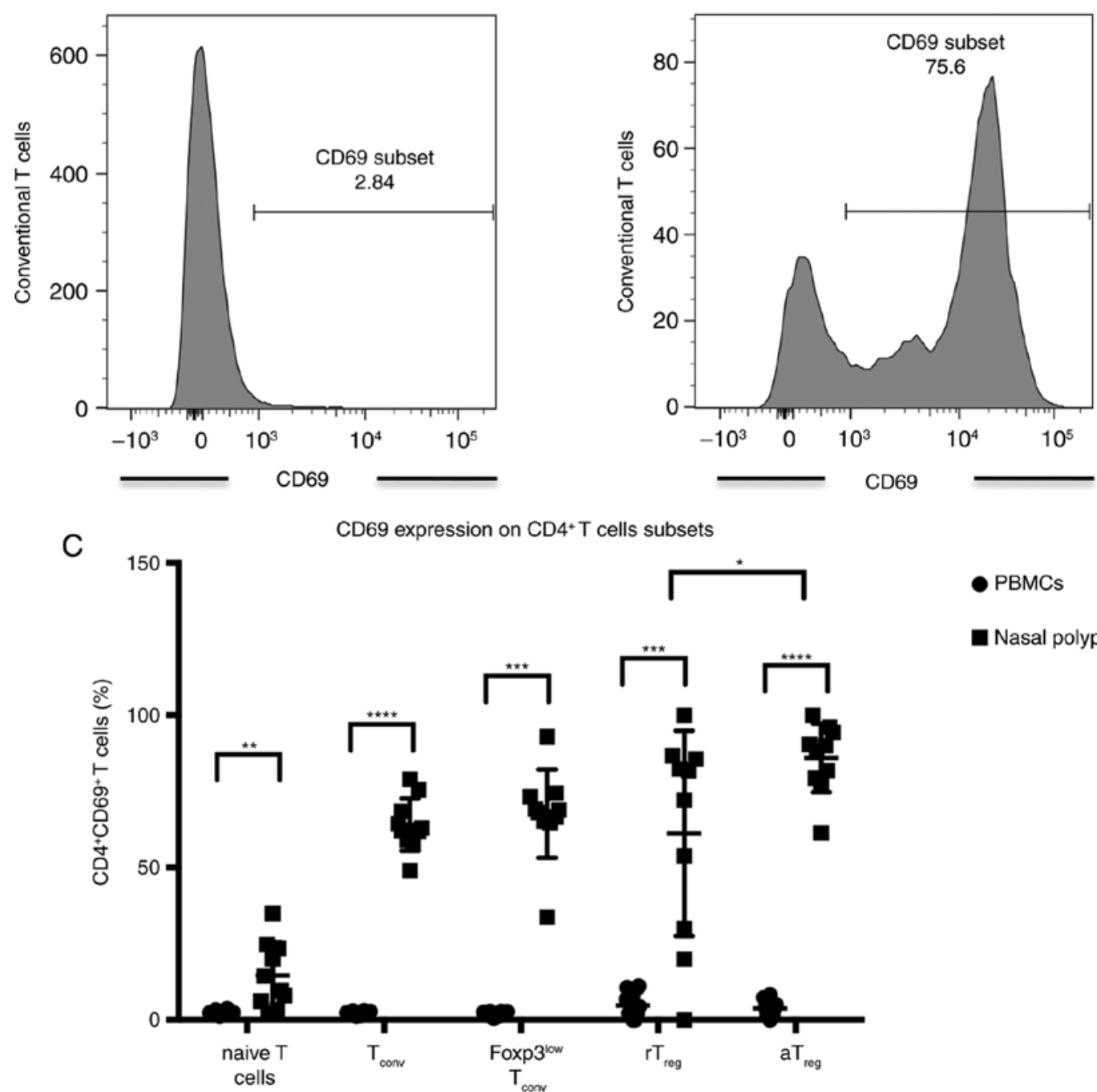

Figure 4. (A) Incidence of CD4+ naïve $\mathrm{T}$ cells, $\mathrm{T}_{\text {conv }}$, FoxP3low $\mathrm{T}_{\text {conv }}, \mathrm{rT}_{\mathrm{reg}}$ and $\mathrm{T}_{\text {reg }}$ in PBMCs and nasal polyps in patients with CRSwNP. (B) Expression of CD69 in $\mathrm{T}_{\text {conv }}$ in PBMCs and nasal polyps in patients with CRSwNP. (C) Expression of CD69 in CD4+ T cell subsets in PBMCs and nasal polyps in patients with CRSwNP. Data are presented as the mean \pm standard deviation of 11 patients. ${ }^{*} \mathrm{P}<0.05,{ }^{* *} \mathrm{P}<0.01,{ }^{* * *} \mathrm{P}<0.001$ and ${ }^{* * * *} \mathrm{P}<0.0001$. CD, cluster of differentiation; $\mathrm{T}_{\text {conv }}$, conventional memory $\mathrm{T}$ cell; $\mathrm{r}_{\text {reg }}$, resting regulatory $\mathrm{T}$ cell; $\mathrm{a}_{\text {reg }}$, activated regulatory $\mathrm{T}$ cell; $\mathrm{CRSwNP}$, chronic rhinosinusitis with nasal polyps.

To the best of our knowledge, this is the first study to describe resident memory $\mathrm{T}$ cells in nasal polyps compared with PBMCs from patients with CRSwNP. CD8 ${ }^{+} \mathrm{T}_{\mathrm{rm}}$ dominated $\mathrm{CD} 4^{+} \mathrm{T}_{\mathrm{rm}}$ within nasal polyps. The role of $\mathrm{T}_{\mathrm{rm}}$ in nasal polyps as a pathogenic trigger of the local inflammatory reaction must be further investigated in future studies; however, the results of the present study suggest local regulation of the immune response within the nasal polyps. Thus, $\mathrm{T}_{\mathrm{rm}}$ can be may be a potential trigger in the pathogenesis of nasal polyps. 


\section{Acknowledgements}

Not applicable.

\section{Funding}

Dr Niklas Beyersdorf was supported by the Deutsche Forschungsgemeinschaft (DFG) (SFB/TR 124 FungiNet, Project C6).

\section{Availability of data and materials}

All data generated or analyzed during this study are included in this published article.

\section{Authors' contributions}

PI performed all experiments, analyzed the results and was the main author of the manuscript. XD, NB and TK conceived the study and analyzed the results. NK, RH and CG analyzed the data and were major contributors to the manuscript. $\mathrm{SH}$ conceived the study, analyzed the results and was a major contributor to the manuscript. All authors read and approved the final manuscript.

\section{Ethics approval and consent to participate}

The study was approved by the Ethics Board of the Medical Faculty, Julius-Maximilian-University Wuerzburg (vote no. 12/06). Ethics approval and written informed consent have been obtained from every patient.

\section{Consent for publication}

Not applicable.

\section{Competing interests}

The authors declare that there are no competing interests.

\section{References}

1. Bachert $\mathrm{C}$ and Akdis CA: Phenotypes and emerging endotypes of chronic rhinosinusitis. J Allergy Clin Immunol Pract 4: 621-628, 2016.

2. Ickrath P, Kleinsasser N, Ding X, Ginzkey C, Beyersdorf N, Hagen R, Kerkau T and Hackenberg S: Characterization of T-cell subpopulations in patients with chronic rhinosinusitis with nasal polyposis. Allergy Rhinol (Providence) 8: 139-147, 2017.

3. Miyara M, Yoshioka Y, Kitoh A, Shima T, Wing K, Niwa A, Parizot C, Taflin C, Heike T, Valeyre D, et al: Functional delineation and differentiation dynamics of human $\mathrm{CD}^{+} \mathrm{T}$ cells expressing the Fox P3 transcription factor. Immunity 30: 899-911, 2009.

4. Ponikau JU, Sherris DA, Kern EB, Homburger HA, Frigas E, Gaffey TA and Roberts GD: The diagnosis and incidence of allergic fungal sinusitis. Mayo Clin Proc 74: 877-884, 1999.

5. Pant H, Hughes A, Miljkovic D, Schembri M, Wormald P, Macardle P, Grose R, Zola H and Krumbiegel D: Accumulation of effector memory $\mathrm{CD} 8^{+} \mathrm{T}$ cells in nasal polyps. Am J Rhinol Allergy 27: e117-e126, 2013.

6. Pant $\mathrm{H}$ and Macardle P: CD8(+) T cells implicated in the pathogenesis of allergic fungal rhinosinusitis. Allergy Rhinol (Providence) 5: 146-156, 2014.
7. Bachert C, Zhang N, Patou J, van Zele T and Gevaert P: Role of staphylococcal superantigens in upper airway disease. Curr Opin Allergy Clin Immunol 8: 34-38, 2008.

8. Van Zele T, Gevaert P, Holtappels G, van Cauwenberge P and Bachert C: Local immunoglobulin production in nasal polyposis is modulated by superantigens. Clin Exp Allergy 37: 1840-1847, 2007.

9. Ickrath P, Kleinsasser N, Ding X, Ginzkey C, Beyersdorf N, Kerkau T, Hagen R and Hackenberg S: Impact and modulations of peripheral and edaphic B cell subpopulations in chronic rhinosinusitis with nasal polyposis. Clin Exp Otorhinolaryngol: Feb 8 , 2018. (Epub ahead of print). doi: 10.21053/ceo.2017.01389.

10. Bromley SK, Thomas SY and Luster AD: Chemokine receptor CCR7 guides $\mathrm{T}$ cell exit from peripheral tissues and entry into afferent lymphatics. Nat Immunol 6: 895-901, 2005.

11. Matloubian M, Lo CG, Cinamon G, Lesneski MJ, Xu Y, Brinkmann V, Allende ML, Proia RL and Cyster JG: Lymphocyte egress from thymus and peripheral lymphoid organs is dependent on S1P receptor 1. Nature 427: 355-360, 2004.

12. Skon CN, Lee JY, Anderson KG, Masopust D, Hogquist KA and Jameson SC: Transcriptional downregulation of S1pr1 is required for the establishment of resident memory $\mathrm{CD} 8^{+} \mathrm{T}$ cells. Nat Immunol 14: 1285-1293, 2013.

13. Mackay LK, Braun A, Macleod BL, Collins N, Tebartz C, Bedoui S, Carbone FR and Gebhardt T: Cutting edge: CD69 interference with sphingosine-1-phosphate receptor function regulates peripheral T cell retention. J Immunol 194: 2059-2063, 2015.

14. Schenkel JM and Masopust D: Tissue-resident memory T cells. Immunity 41: 886-897, 2014.

15. Brown MN, Fintushel SR, Lee MH, Jennrich S, Geherin SA, Hay JB, Butcher EC and Debes GF: Chemoattractant receptors and lymphocyte egress from extralymphoid tissue: Changing requirements during the course of inflammation. J Immunol 185: 4873-4882, 2010.

16. Jiang X, Clark RA, Liu L, Wagers AJ, Fuhlbrigge RC and Kupper TS: Skin infection generates non-migratory memory $\mathrm{CD}^{+} \mathrm{T}(\mathrm{RM})$ cells providing global skin immunity. Nature 483: 227-231, 2012.

17. Schrijvers R, Gilissen L, Chiriac AM and Demoly P: Pathogenesis and diagnosis of delayed-type drug hypersensitivity reactions, from bedside to bench and back. Clin Transl Allergy 5: 31, 2015.

18. Aoki M, Aoki H, Ramanathan R, Hait NC and Takabe K: Sphingosine-1-phosphate signaling in immune cells and inflammation: Roles and therapeutic potential. Mediators Inflamm 2016: 8606878,2016

19. Ma C, Mishra S, Demel EL, Liu Y and Zhang N: TGF- $\beta$ controls the formation of kidney-resident $\mathrm{T}$ cells via promoting effector T cell extravasation. J Immunol 198: 749-756, 2016.

20. Bergsbaken T and Bevan MJ: Proinflammatory microenvironments within the intestine regulate the differentiation of tissue-resident CD8(+) T cells responding to infection. Nat Immunol 16: 406-414, 2015.

21. Wang X, Zhang N, Bo M, Holtappels G, Zheng M, Lou H, Wang $\mathrm{H}$, Zhang L and Bachert C: Diversity of TH cytokine profiles in patients with chronic rhinosinusitis: A multicenter study in Europe, Asia, and Oceania. J Allergy Clin Immunol 138: 1344-1353, 2016.

22. Mackay LK and Kallies A: Transcriptional regulation of tissue-resident lymphocytes. Trends Immunol 38: 94-103, 2017.

23. Anderson KG, Sung H, Skon CN, Lefrancois L, Deisinger A, Vezys V and Masopust D: Cutting edge: Intravascular staining redefines lung CD8 T cell responses. J Immunol 189: 2702-2706, 2012.

24. Casey KA, Fraser KA, Schenkel JM, Moran A, Abt MC, Beura LK, Lucas PJ, Artis D, Wherry EJ, Hogquist K, et al: Antigen-independent differentiation and maintenance of effector-like resident memory T cells in tissues. J Immunol 188: 4866-4875, 2012.

25. Sallusto F, Lenig D, Forster R, Lipp M and Lanzavecchia A: Two subsets of memory $\mathrm{T}$ lymphocytes with distinct homing potentials and effector functions. Nature 401: 708-712, 1999.

26. Steinert EM, Schenkel JM, Fraser KA, Beura LK, Manlove LS, Igyártó BZ, Southern PJ and Masopust D: Quantifying memory CD8 T cells reveals regionalization of immunosurveillance. Cell 161: 737-749, 2015.

27. Steinbach K, Vincenti I, Kreutzfeldt M, Page N, Muschaweckh A, Wagner I, Drexler I, Pinschewer D, Korn T and Merkler D: Brain-resident memory T cells represent an autonomous cytotoxic barrier to viral infection. J Exp Med 213: 1571-1587, 2016. 
28. Gebhardt T, Whitney PG, Zaid A, Mackay LK, Brooks AG, Heath WR, Carbone FR and Mueller SN: Different patterns of peripheral migration by memory $\mathrm{CD} 4^{+}$and $\mathrm{CD} 8^{+} \mathrm{T}$ cells. Nature 477: 216-219, 2011.

29. Sakaguchi S, Yamaguchi T, Nomura T and Ono M: Regulatory T cells and immune tolerance. Cell 133: 775-787, 2008.

30. Robinson DS: The role of regulatory T lymphocytes in asthma pathogenesis. Curr Allergy Asthma Rep 5: 136-141, 2005.

31. Lynch L, Michelet X, Zhang S, Brennan PJ, Moseman A, Lester C, Besra G, Vomhof-Dekrey EE, Tighe M, Koay HF, et al: Regulatory iNKT cells lack expression of the transcription factor PLZF and control the homeostasis of T(reg) cells and macrophages in adipose tissue. Nat Immunol 16: 85-95, 2015.

32. Luo CT, Liao W, Dadi S, Toure A and Li MO: Graded Foxol activity in Treg cells differentiates tumour immunity from spontaneous autoimmunity. Nature 529: 532-536, 2016.
33. Schmidt JD, Ahlström MG, Johansen JD, Dyring-Andersen B, Agerbeck C, Nielsen MM, Poulsen SS, Woetmann A, Ødum N, Thomsen AR, et al: Rapid allergen-induced interleukin-17 and interferon- $\gamma$ secretion by skin-resident memory $\mathrm{CD}^{+} \mathrm{T}$ cells. Contact Dermatitis 76: 218-227 2016.

34. Park CO and Kupper TS: The emerging role of resident memory $\mathrm{T}$ cells in protective immunity and inflammatory disease. Nat Med 21: 688-697, 2015.

35. Sathaliyawala T, Kubota M, Yudanin N, Turner D, Camp P, Thome JJ, Bickham KL, Lerner H, Goldstein M, Sykes M, et al: Distribution and compartmentalization of human circulating and tissue-resident memory T cell subsets. Immunity 38: 187-197, 2013. 